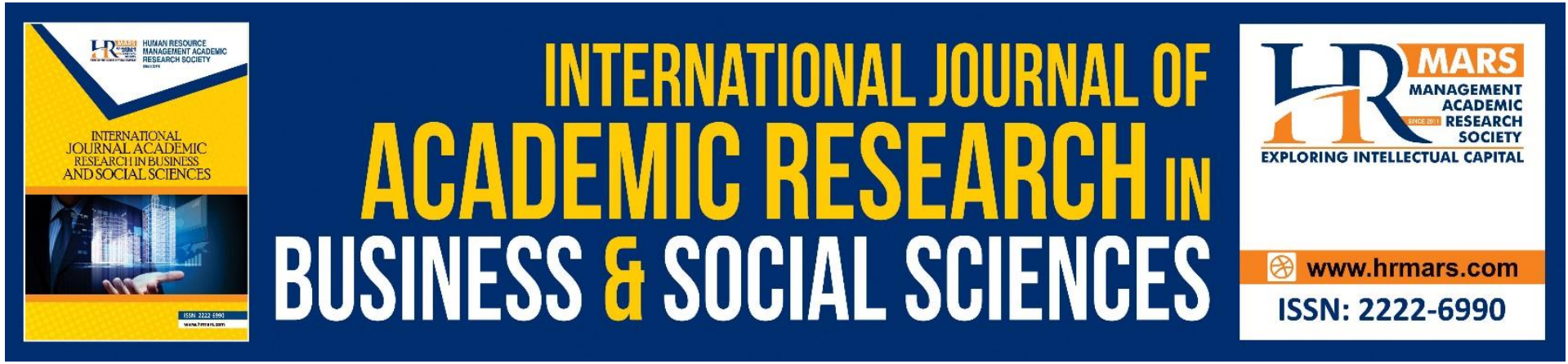

\title{
The Relationship between Perceived Social Support, Self- Esteem and Career Decision Self-Efficacy among First Year Undergraduate Students
}

\author{
Nor Olivia Yan Abdullah \& Samsilah Roslan
}

To Link this Article: http://dx.doi.org/10.6007/IJARBSS/v11-i8/10782

DOI:10.6007/IJARBSS/v11-i8/10782

Received: 05 June 2021, Revised: 10 July 2021, Accepted: 28 July 2021

Published Online: 12 August 2021

In-Text Citation: (Abdullah \& Roslan, 2021)

To Cite this Article: Abdullah, N. O. Y., \& Roslan, S. (2021). The Relationship between Perceived Social Support, Self-Esteem and Career Decision Self-Efficacy among First Year Undergraduate Students. International Journal of Academic Research in Business and Social Sciences, 11(8), 845-859.

Copyright: (c) 2021 The Author(s)

Published by Human Resource Management Academic Research Society (www.hrmars.com)

This article is published under the Creative Commons Attribution (CC BY 4.0) license. Anyone may reproduce, distribute, translate and create derivative works of this article (for both commercial and non-commercial purposes), subject to full attribution to the original publication and authors. The full terms of this license may be seen at: http://creativecommons.org/licences/by/4.0/legalcode

Vol. 11, No. 8, 2021, Pg. 845 - 859

Full Terms \& Conditions of access and use can be found at http://hrmars.com/index.php/pages/detail/publication-ethics 


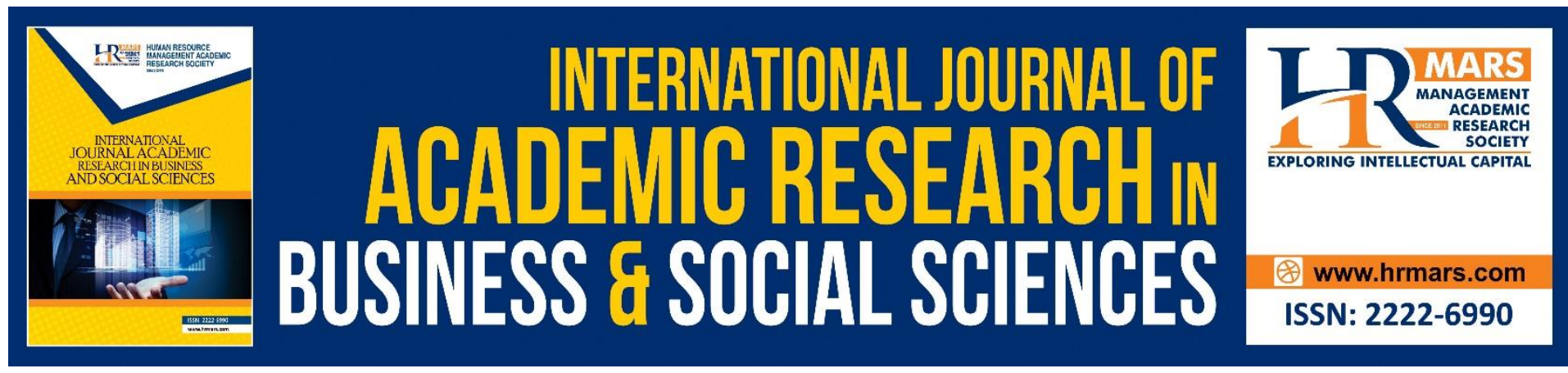

\title{
The Relationship between Perceived Social Support, Self-Esteem and Career Decision Self- Efficacy among First Year Undergraduate Students
}

\author{
Nor Olivia Yan Abdullah² \& Samsilah Roslan ${ }^{1,2}$ \\ ${ }^{1}$ Institute of Social Science Studies, Universiti Putra Malaysia, Putra Infoport, 43400, \\ Serdang, Selangor, ${ }^{2}$ Faculty of Educational Studies, Universiti Putra Malaysia, Putra \\ Infoport, 43400, Serdang, Selangor. \\ Email: samsilah@upm.edu.my
}

\begin{abstract}
Career decision-making is one of the important processes that students, particularly university students, need to emphasise. This study investigates the relationship between three social support dimensions (friends, family, and significant others), self-esteem, and career decision self-efficacy among undergraduates. Cluster random sampling was employed to recruit 190 first-year social science students from a public university in Malaysia. Regression analysis indicated that friend support and self-esteem were positively associated with career decision self-efficacy. The study has also shown that, when it comes to career decision self-efficacy of university students, parental support and support from significant others did not seem to have a significant role. These results can provide information to students, parents, colleges, and career counsellors in the creation of strategies or services that may improve the student's self-efficiency in career decisions.
\end{abstract}

Keyword: Perceived Social Support, Self-Esteem, Career Decision Self-Efficacy, Undergraduates, Malaysia.

\section{Introduction}

The researchers of career psychology have a vigorous interest in the study of career decidedness among undergraduate students (e.g., Harlow \& Bowman, 2016; Penn \& Lent, 2018; Gianakos, 1999; Wang et al., 2006). Career decision-making is also assumed as one of the vital tasks in the phase of both late adolescence and early adulthood (Super, 1990). For many adolescents who decide to continue their studies in higher education, entering college is the primary step into adulthood (Santrock, 2014; Vondracek \& Porfeli, 2003), which is believed to significantly influence their career path (Budiningsih, 2012).

University graduates have a greater chance of having more stable employment, higher earnings, more career mobility, and higher career achievement (Montgomery \& Côté, 2003). In relation to this, career decision is deemed important to be emphasized by students, 
especially college students. According to Gordon and Steele (2003), 50\% of students who have just entered college, were still undecided about their careers. Kelly and Shin (2009), explained that between $11 \%$ and $13 \%$ of new students at university level still do not have an idea about their major in college. Study by Mojgan et al. (2013), on Iranian undergraduate's level shows that almost $85 \%$ were still doubtful about their major. Research conducted in Malaysia by Maznizam and Abdullah (2013), also showed that undergraduate students experience low and moderate scores on career readiness. This is further supported by Jelas et al. (2013), who found that among graduates who do not work after graduation, the career decision self-efficacy is between low and moderate.

In line with Bandura's self-efficacy theory, students who have low levels of career decision self-efficacy may induce inhibition of career-decision, whereas stronger levels of career decision self-efficacy would be more likely to lead to increased involvement in careerdecision behavior (Taylor \& Betz, 1983; Betz, Klein, \& Taylor, 1996). In relation to this, there are other factors that need to be taken into consideration in determining a student's career path and the extent to which he or she is confident in determining his or her career at the university. One of the factors that need to be looked into is student's self-esteem. Selfesteem refers to the degree to which the student is confident in his or her ability. Self-esteem is acknowledged as a factor that can influence students to have confidence in deciding on a career. However, most students are still struggling to decide their career when they enter the university. General confidence itself among students was found to be an issue as Hassan et al. (2008), stated that students seem to not have confidence in expressing their opinions.

Maslow's theory mentioned that self-esteem is fundamental to fulfil all needs. When these needs are satisfied, the person feels self-confident and valuable as a person in the world (Simons et al. 1987). Other than that, dimensional theory of affect shows that someone with high self-esteem may feel less anxiety (Brown \& Marshall in Park et al., 2018). Similarity, Park et al. (2018), also mentioned that self-esteem is one of the important variables that affect occupational and career decision making. Many previous studies have examined these two variables. For example, a study by Resnick et al. (1970) concluded that low self-esteem is associated with career decision difficulties.

In helping students shape careers to prepare them for the work environment, understanding the importance of social support in career decision-making self-efficacy is required. The social support variables (e.g., family, friends, and significant others) will influence them in deciding which career they want. The Zimet Model of Social Support stipulated that individuals will be more confident and have positive self-efficacy when he or she receives support from friends or family members and this can also affect decision making (Wang et al., 2015). Based on these theories stipulated relationship were constructed (Figure 1). 
Figure 1: Theoretical framework of study

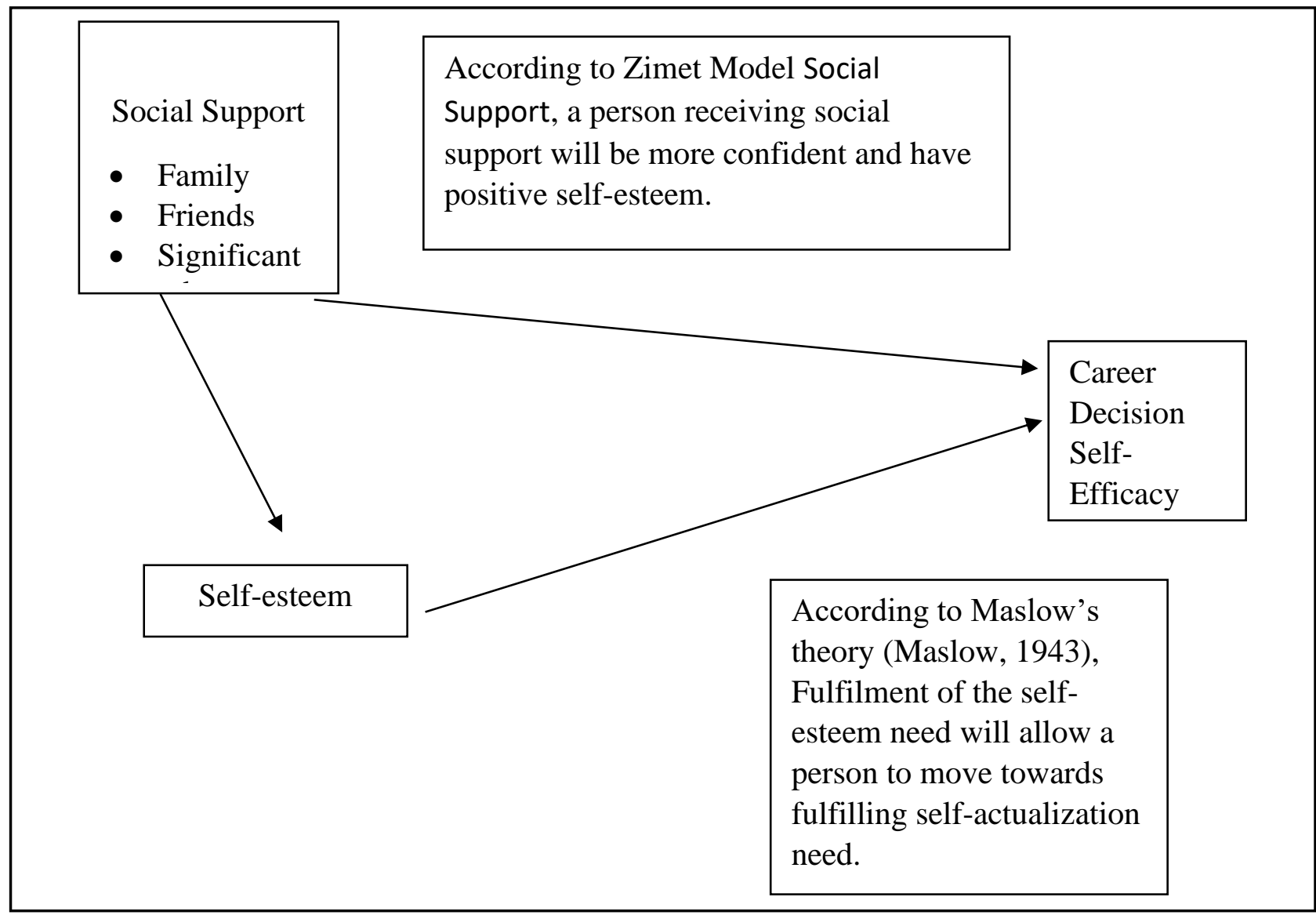

Nowadays, most students who are pursuing university studies are still unable to determine their careers choices (Talib, M. A., \& Aun, T. K., 2009). This is normally attributed to them having a low level of self-confidence in determining their careers. Another related factor is low information about the career ( $\mathrm{Li}$ et al. 2015). This is a cause for concern as during high school years, students are expected to make important career decision regarding their career plans and educational pathway (Seligman, 1994).

The main issue is there are many students who are still unable to embark on a career decision process and this means that these students are still not ready to enter the work environment. The lack of readiness is the most common factor associated with the students lack engagement in making career decision ( $\mathrm{Li}$, et al. 2015). In addition, the role of the family and peer is also continuously highlighted in this issue (Turner et al., 2003) (Zhang \& Huang, 2018). Other studies pinpoint on the influence of self-esteem in the career decision process of students (Ali \& Shah, 2013).

It goes without saying that one of the most important decision that students should be aware of their career choice (Dorgan \& Kazak, 2010) as it can affect their future life. However, deciding on a future career is not always easy and many individuals find it difficult to make career decisions (Chen \& Liew, 2015). According to Joo (2014), college graduates have difficulty in constructing discussions about career process and this can later on affect their success in getting a job. 
A recent study conducted by Park et al. (2018) shows that self-esteem affect career decision self-efficacy but not social support. Another study conducted by Hasrin et al. in 2016 on technical engineering students found that there are significant relationships between selfesteem, parental social support, and career decision self-efficacy. However, most studies career decision and social support have not looked into the specific contributions of dimensions of social support such as family, friends, and significant others. This needs to be studied as it will help educationists to look into the most important enabler to help overcome the issue of low career decision among students. Therefore, this study will examine the influence of dimensions of social support and self-esteem that can affect career decision selfefficacy among first-year undergraduates' students.

\section{Methods}

The research design for this study is descriptive correlational in nature. The population of this study is $\mathbf{5 1 3}$ first-year undergraduates' students in the faculty of social science at a public university in Malaysia. Based on the sample size calculated using Cochran's formula (Kotrlik \& Higgins, 2001), the minimum sample size needed was 175 . As suggested by Salkind (2010), a sum of $40 \%$ was added to the minimum sample size to cater for potential non-response error. This brought the total of sample size to 245 . In order to get the samples, cluster random sampling was used. The faculty has six academic programmes, and two academic programmes were chosen. Questionnaires were sent and the total response received was 190 which exceeded the minimum sample size of 175 based on Cochran's formula.

Several instruments were used in this study. The Multidimensional Scale of Perceived Social Support (MSPSS) is a research tool designed to measure perceptions of social support from three sources namely family, friends, and significant others. This instrument contains 12 items covering three sub-scales. In addition, the instrument has 7-point rating scales which is from very strongly disagree (1), strongly disagree (2), mildly disagree (3), neutral (4), mildly agree (5), strongly agree (6), and very strongly agree (7). The three categories which are parent, peer, and significant others in this instrument had reliability coefficients of $0.88,0.82$ and 0.94 respectively.

The Rosenberg Self-Esteem Scale, developed by Morris Rosenberg (1965), is a ten item that measures that state of self-esteem by asking questions about current feelings, for example, ("I feel that I am a person of worth, at least on an equal plane with others" and "At times I think that I am no good at all"). This instrument is highly valid and reliable. The internal validity measured with a Cronbach's alpha was.87.

The career decision self-efficacy scale-short form is an instrument made by Betz, Klein, \& Taylor, (1996). This instrument consisted of five dimensions which are self-appraisal, occupational information, goal selection, making plans for the future, and problem-solving (Arlinkasari et al., 2016). A study conducted by Luzzo (1993), in Australia showed that the reliability of this instrument was .83 .

To assess the reliability of the instruments, the researcher conducted a pilot study of 40 respondents. The respondents are a pool selected from the population determined by the researcher among first-year undergraduate students in a university. Regression analysis is used in this study for the analysis of data using SPSS package version 25. 
Preliminary data analysis shows that the data fulfils the assumptions needed for regression analysis. Table 1 depicts the skewness and kurtosis values for social support, self-esteem and career decision self-efficacy. The values were all found to be within the accepted range of 1 to -1 for skewness and +2.8 to -2.8 for kurtosis (Kline, 2005)

Table 1: Skewness and Kurtosis Values

\begin{tabular}{lcc}
\hline Variables & Skewness & Kurtosis \\
\hline Perceived social support & -.961 & 1.008 \\
self-esteem & -.331 & .487 \\
career decision self-efficacy & -.225 & -.220
\end{tabular}

Tolerance and VIF values for predictor variables in the career decision self-efficacy (CDSE) model are also computed (Table 2) to check for multicollinearity. According to Hair et al. (1995) the acceptable level of multicollinearity should be indicated by tolerance value of less than 0.19 and VIF value greater than 5.3. From the table, it is found that there is no predictor variable that has a tolerance value smaller than 0.19 and a VIF value more than 5.3. Thus, multicollinearity does not pose as a threat for the regression model.

Table 2: Collinearity value for the variables

\begin{tabular}{lcc}
\hline \multirow{2}{*}{ Model } & \multicolumn{2}{c}{ Collinearity } \\
\cline { 2 - 3 } & Tolerance & VIF \\
\hline Family $\left(X_{1}\right)$ & .878 & 1.617 \\
Friend $\left(X_{2}\right)$ & .766 & 1.306 \\
Significant others $\left(X_{3}\right)$ & .621 & 1.610 \\
Self-esteem $\left(X_{4}\right)$ & .857 & 1.167 \\
\hline
\end{tabular}

\section{Results}

\section{Demographic Information}

The targeted respondents in this study is 245 . Out of the total targeted, the researcher only received back 190 questionnaires answered by first-years social science students. Table 3 shows the percentage and frequency of respondent's demographic information. 
Table 3: Demographic of respondent

\begin{tabular}{llcc}
\hline Data & Category & $\begin{array}{c}\text { Frequency } \\
(\mathbf{n = 1 9 0 )}\end{array}$ & Percentage (\%) \\
\hline Gender & Female & 125 & 62.8 \\
& Male & 65 & 34.2 \\
\hline Age group & $18-22$ years old & 134 & 71.5 \\
& 23-26 years old & 56 & 29.5 \\
\hline Ethnicity & Malay & 76 & 40 \\
& Chinese & 19 & 10 \\
& Indian & 8 & 4.2 \\
& Bumiputera & 87 & 45.8 \\
& Sabah/Sarawak & & \\
\hline Parental Educational Level & UPSR & 17 & 8.9 \\
& & & \\
& SPM & 43 & 22.6 \\
& STPM & 41 & 21.6 \\
& Degree & 82 & 43.2 \\
& Master/PhD & 7 & 3.7 \\
\hline
\end{tabular}

From table, it was concluded that $62.8 \%(n=125)$ female students and $34.2 \%(n=65)$ male students participated in this study. Most of them are in the age group of 18-26 years old $(71.5 \%, n=132)$ and the rest are $23-26$ years old $(29.5 \%, n=56)$. In terms of ethnic group, the result indicates that majority of the respondent in this study are Bumiputera Sabah/Sarawak $(45.8 \%, n=87)$, followed by Malay $(40 \%, n=76)$, Chinese $(10 \%, n=19)$ and the remaining $10 \%$ $(n=8)$ of respondents are Indians. Parental educational level is varied, where the result shows that most parents of the students have Degree $(43.2 \%, n=82)$, followed by SPM $(22.6 \%, n=$ $43)$, and STPM. $(21.6 \%, n=41)$. A small amount of 3.7\% $(n=7)$ have Master $/ P h D$.

\section{Level of Perceived Social Support}

The finding shows that $71.6 \%(n=136)$ of the respondents in this study have high level of perceived social support (Table 3$)$. A total of $24.7 \%(n=47)$ of the respondents score moderate level of perceived social support and the rest is $3.7 \%(n=7)$ of respondents have low level of social support. Meanwhile, for subscales, the finding shows that $71.1 \%(n=135)$ respondents score high level of support from their family, followed by $26 \%(n=43)$ on moderate level. Only $6.3 \%(n=12)$ of the total respondents score low on this subscale. Similarly, a total of $67.9 \%(n=135)$ respondent score high level of support from friends, $26.3 \%(n=50)$ respondents were at moderate level and the rest were at low level $(n=11,5.8 \%)$. For significant others, $71.6 \%(n=136)$ respondents were at high level, $21.6 \%(n=41)$ respondents score moderate level and only $6.8 \%(n=13)$ respondents were at low level (Table 2$)$. Generally, most of the respondents in this study reported high level of perceived social support $(M=3.955$, $\mathrm{SD}=.694)$. 
Table 3: The level of perceived social support

\begin{tabular}{lcccc}
\hline Variable/subscale & $\begin{array}{c}\text { Mean score } \\
\text { (M) }\end{array}$ & $\begin{array}{c}\text { Standard Deviation } \\
\text { (SD) }\end{array}$ & Frequency & $\begin{array}{c}\text { Percentage } \\
\text { (\%) }\end{array}$ \\
\hline $\begin{array}{l}\text { Overall perceived } \\
\text { social support }\end{array}$ & 3.955 & .694 & & \\
Low & & & 7 & 3.7 \\
Moderate & & 47 & 24.7 \\
High & & 136 & 71.6 \\
\hline Family & & & \\
Low & 4.001 & .904 & 12 & 6.3 \\
Moderate & & 43 & 22.6 \\
High & & 135 & 71.1 \\
\hline Friends & & & \\
Low & 3.846 & .815 & 11 & 5.8 \\
Moderate & & 50 & 26.3 \\
High & & & 129 & 67.9 \\
\hline Significant others & 4.015 & .881 & & \\
Low & & & 13 & 6.8 \\
Moderate & & 41 & 21.6 \\
High & & 136 & 71.6 \\
\hline
\end{tabular}

\section{Level of Self-Esteem}

The results show that only $58.4 \%(n=111)$ of respondents score high on the level of selfesteem while a total $39.5 \%(n=75)$ of respondents score moderate and the rest $(2.1 \%, n=4)$ reported low level of self-esteem (Table 4).

Table 4: The level of self-esteem

\begin{tabular}{lcccc}
\hline Variable/subscale & $\begin{array}{c}\text { Mean score } \\
\text { (M) }\end{array}$ & $\begin{array}{c}\text { Standard } \\
\text { Deviation } \\
\text { (SD) }\end{array}$ & Frequency & Percentage (\%) \\
\hline Overall Self-esteem & 3.745 & .613 & & \\
Low & & 4 & 2.1 \\
Moderate & & 75 & 39.5 \\
High & & 111 & 58.4 \\
\hline
\end{tabular}

Overall, the level of self-esteem among first-year social science undergraduates' students was moderately high $(\mathrm{M}=3.745, \mathrm{SD}=.613)$ and this is a cause for concern for educators and policy makers.

\section{Level of Career Decision self-efficacy}

Table 5 shows the level of career decision self-efficacy and subscale among the respondents in this study. The finding shows that the overall level of career decision self-efficacy among first-year undergraduates' students studied is slightly high $(M=3.919, S D=.551)$. A total of $68.9 \%(n=131)$ respondents have high career decision self-efficacy scores. This is followed by $30.5 \%(n=58)$ of the respondents scoring a moderate level of career decision self-efficacy and only $0.5 \%(n=1)$ have low level of career decision self-efficacy. 
Table 5: The level of career decision self-efficacy

\begin{tabular}{|c|c|c|c|c|}
\hline Variable/subscale & $\begin{array}{c}\text { Mean } \\
\text { score } \\
\text { (M) }\end{array}$ & $\begin{array}{c}\text { Standard } \\
\text { Deviation } \\
\text { (SD) }\end{array}$ & Frequency & $\begin{array}{c}\text { Percentage } \\
\text { (\%) }\end{array}$ \\
\hline $\begin{array}{l}\text { Overall Career } \\
\text { Decision Self-Efficacy }\end{array}$ & 3.919 & .551 & & \\
\hline Low & & & 1 & .5 \\
\hline Moderate & & & 58 & 30.5 \\
\hline High & & & 131 & 68.9 \\
\hline Self-appraisal & 3.971 & .616 & & \\
\hline Low & & & 2 & 1.1 \\
\hline Moderate & & & 58 & 30.5 \\
\hline High & & & 130 & 68.4 \\
\hline $\begin{array}{l}\text { Occupational } \\
\text { information }\end{array}$ & 3.953 & .657 & & \\
\hline Low & & & 4 & 2.1 \\
\hline Moderate & & & 58 & 30.5 \\
\hline High & & & 128 & 67.8 \\
\hline Goal selection & 3.882 & .661 & & \\
\hline Low & & & 3 & 1.6 \\
\hline Moderate & & & 66 & 34.7 \\
\hline High & & & 121 & 63.7 \\
\hline $\begin{array}{l}\text { Making plans for the } \\
\text { future }\end{array}$ & 4.018 & .608 & & \\
\hline Low & & & 1 & .5 \\
\hline Moderate & & & 56 & 29.5 \\
\hline High & & & 133 & 70.0 \\
\hline Problem-solving & 3.801 & .634 & & \\
\hline Low & & & 4 & 2.1 \\
\hline Moderate & & & 70 & 36.8 \\
\hline High & & & 116 & 61.1 \\
\hline
\end{tabular}

In terms of subscales under career decision self-efficacy, 68.4\% $(n=130)$ respondents have high level of self-appraisal, $30.3 \%(n=58)$ have moderate level of self-appraisal and only $1.1 \%$ $(n=2)$ have low level of self-appraisal. This means that a majority of respondents feel confident to evaluate their abilities related career. For the second subscale, which is occupational 
information, a total of $67.8 \%(n=128)$ respondents score high level of occupational information. Those in moderate level of occupational information made $30.5 \%(n=58)$ of the respondents and the rest $(2.1 \%, n=4)$ have low level of occupational information. This means that most students know how to find information about career and occupations.

The third subscale is goal selection, where $63.7 \%(n=121)$ respondents scored high level, $34.7 \%(n=66)$ scored moderate level, and $1.6 \%(n=3)$ have low level of goal selection. This means that most students were confident to select their goals when it comes to career. In addition, $70.0 \%$ ( $n=133$ ) respondents score high level in term of making plans for the future followed by $29.5 \%(n=56)$ in moderate level and the rest $0.5 \%(n=1)$ of respondents at low level of making plans for the future which means that student's ability to make decision about future. Last subscale shows that $61.1 \%(n=116)$ of respondents score in high level of problemsolving. Next, $36.8 \%(n=70)$ respondents in moderate level and only $2.1 \%(n=4)$ respondents score a low level of problem-solving.

It can be concluded that most of first-year science social undergraduates' students studied score a relatively high level of career decision self-efficacy. A high level of career decision selfefficacy means that the respondents have highest level of self-appraisal, occupational information, goal selection, making plans for the future, and problem solving.

\section{Multiple Linear Regression Analysis}

To find the result for hypothesis 4, a model of linear regression consisting of four of predictor variables was proposed. The predictor variables are dimensions of social support, comprising family $\left(X_{1}\right)$, friend $\left(X_{2}\right)$, and significant others $\left(X_{3}\right)$, and self-esteem $\left(X_{4}\right)$. This variable will be tested according to the equation of the multiple linear regression model below.

$$
Y(C D S E)=B_{0}+b_{1}\left(X_{1}\right)+b_{2}\left(X_{2}\right)+b_{3}\left(X_{3}\right)+b_{4}\left(X_{4}\right)+r
$$

where:

$$
\begin{aligned}
& Y(C D S E)=\text { Career Decision Self-Efficacy (CDSE) } \\
& B_{0}=\text { Constant value } \\
& b_{1}-b_{4}=\text { Beta coefficient weights } \\
& X_{1}=\text { Family } \\
& X_{2}=\text { Friend } \\
& X_{3}=\text { Significant others } \\
& X_{4}=\text { Self-esteem } \\
& r=\text { error }
\end{aligned}
$$

To determine the best predictor variables in predicting career decision self-efficacy (CDSE), the "Enter" regression method was used. It was found that friend $(\boldsymbol{\beta}=.153, t=3.363, p<.000)$ and self-esteem $(\boldsymbol{\beta}=.379, \mathrm{t}=6.635, \mathrm{p}<.000)$ are significant predictors in explaining the variance in career decision self-efficacy. However, family $(\beta=.028, t=-608, p>.000)$ and significant others $(\beta=.067, t=1.442, p>.000)$ are not predictors of career decision selfefficacy. This means that only "friends" as a dimension under social support predict career 
decision self-efficacy. As hypothesised, self-esteem significantly predict career decision selfefficacy.

Data in Table 5 also shows that the model coefficients of CDSE for $b_{1}$ is $.028, b_{2}$ is $.153, b_{3}$ is .067 and, $b_{4}$ is .379. Therefore, the estimated model is as below:

$$
Y(C D S E)=1.583+.028\left(X_{1}\right)+.153\left(X_{2}\right)+.067\left(X_{3}\right)+.379\left(X_{4}\right)+.238
$$

where:

$$
\begin{aligned}
& Y(C D S E)=\text { Career Decision Self-Efficacy (CDSE) } \\
& B_{0}=\text { Constant value } \\
& b_{1}-b_{4}=\text { Beta coefficient weights } \\
& X_{1}=\text { Family } \\
& X_{2}=\text { Friend } \\
& X_{3}=\text { Significant others } \\
& X_{4}=\text { Self-esteem } \\
& r=\text { error }
\end{aligned}
$$

Table 5: Beta value for career decision self-efficacy

\begin{tabular}{lccccc}
\hline \multicolumn{1}{c}{ Model } & $\begin{array}{c}\text { Unstandardized } \\
\text { Coefficient, B }\end{array}$ & $\begin{array}{c}\text { Std. } \\
\text { Error }\end{array}$ & $\begin{array}{c}\text { Standardized } \\
\text { Coefficient, } \boldsymbol{\beta}\end{array}$ & $\mathbf{t}$ & p- value \\
\hline Constant & 1.531 & .238 & & 6.445 & .000 \\
Family $\left(\mathrm{X}_{1}\right)$ & .028 & .046 & .045 & .608 & .544 \\
Friend $\left(\mathrm{X}_{2}\right)$ & .153 & .045 & .226 & 3.363 & .000 \\
Significant others $\left(\mathrm{X}_{3}\right)$ & .067 & .047 & .108 & 1.442 & .151 \\
Self-esteem $\left(\mathrm{X}_{4}\right)$ & .379 & .057 & .421 & 6.635 & .000 \\
\hline
\end{tabular}

Note: $R=.600 ; R^{2}=.361 ;$ Adj. $R^{2}=.347, F(4,185)=26.075, p<0.0001$

This regression model is significant $\left(\Delta R^{2}=.347, F(4,185), p<.0001\right.$. The predictor variables contributed $34.7 \%$ of the variance in the dependent variable which is career decision selfefficacy (CDSE). Based on Table 5, the highest standardized coefficient ( $\beta$ ) between these four predictor variables is the self-esteem variable $(\beta=.379)$. This proves that self-esteem contributes the most in explaining career decision self-efficacy (CDSE) among first-year undergraduates' students studied. The beta coefficient value for the dimension of friend is the second highest predictor $(\beta=.153)$. The dimension of family and significant others are not significant predictors of career decision self-efficacy. This means that the variable of selfesteem is more influential in predicting and contributing to students' career decision selfefficacy (CDSE) than the variable of social support.

\section{Discussion and Implications}

This study uses inferential analysis to look at the relationship between perceived social support and career decision self-efficacy among first year undergraduate students in Malaysia. The results demonstrated that self-esteem and one dimension under social support which is support from friends significantly affect career decision self-efficacy of students. Between these two predictors, self-esteem has a higher impact on the dependent variable than support from friends. This shows that self-esteem is one of the most important factors 
to focus on in order to increase career decisions self-efficacy among first-year social science undergraduates' students at the university studied.

For practical implication, the results of this study will help parents to better understand the factors that will influence their children's determination of career. Parents can play an important role in guiding and supporting their children. Although parental support does not have significant influence in career decision self-efficacy of their children at university level, many studies have found that it has a very strong influence on self-esteem, especially in the earlier years. Parents should take note that building a high self-esteem and nurturing it in their children will later on have implications on career self-efficacy and ultimately decision making. Parenting methods that can nurture high self-esteem should be mastered and employed. On the other hand, situations and incidences that can tarnish the development of a healthy self-esteem should be avoided by both parents and teachers.

Students themselves can be encouraged to explore more career options in order to increase their career literacy. The more exposure and experience they have, the richer their knowledge reservoir on career options, which will definitely help them in making informed decisions related to careers and perhaps increase their career self-efficacy. As friend support seem to be more influential in the university years, encouraging youths to provide social support to each other in exploring careers may result in increased career self-efficacy. Programmes where youths who have made good career choices guide and facilitate other youths on career options, can be organised to help increase the cumulative career literacy and career selfefficacy in the youth community.

This study reveals that friends can be a powerful source of social support that has a direct influence on the careers that students choose to pursue. The results are consistent with previous research, which showed that there is a connection between peer support and career decision-making in college (Zhang \& Huang, 2018). Career counselling can utilise this information and integrate the role of friends and peers in influencing students' confidence in their career choices.

\section{Limitation and Future Studies}

Future research can be further done to overcome the limitations of the study. As this study used a quantitative method to provide a general overview of the issue, a deeper understanding of the variables of the study can be obtained if qualitative method such as interviews is utilised. Longitudinal studies can also provide more information on long term effects of the predictors on career self-efficacy.

Secondly, this study is limited to respondents in one university in Malaysia and the result and the results of the study are only valid for the student population studied and cannot be applied to all undergraduates' students in Malaysia. It is recommended that future studies include other universities in Malaysia to encompass a more diverse population of Malaysian youths. 


\section{References}

Arlinkasari, F., Rahmatika, R., \& Akmal, S. Z. (2016). The Development of Career Decision Making Self-Efficacy Scale (Indonesia Version). In International Symposium on Business and Social Science, Jeju Island, South Korea (pp. 148-158).

Ali, U., \& Shah, E. (2013). Career decision difficulty as a predictor of environmental mastery and self-esteem in college students. Procedia-Social and Behavioral Sciences, 84, 1119-1123.

Budiningsih, T. B. (2012). Pengambilan keputusan terhadap perencanaan karir ditinjau dari efikasi diri dan ketepatan pilihan karir pada remaja SMA Negeri Kodya Semarang. (Unpublished master's thesis). Gadjah Mada University, Yogyakarta, Indonesia.

Betz, N. E., Klein, K. L., \& Taylor, K. M. (1996). Evaluation of a short form of the career decisionmaking self-efficacy scale. Journal of Career Assessment, 4(1), 47-57.

Chen, L. S., \& Liew, S. A. (2015). Factors Influencing Career Decision-Making Difficulties among Graduating Students from Malaysian Private Higher Educational Institutions. In Proceedings of 8th Asia-Pacific Business Research Conference. Proceedings of 8th AsiaPacific Business Research Conference, (February).

Doğan, T., \& Kazak, M. (2010). The investigation of the relationship between students' decision-making skills and parental attitudes. Procedia-Social and Behavioral Sciences, 2(2), 2556-2560.

Gordon, V., \& Steele, G. (2003). Undecided first-year students: A 25-year longitudinal study. Journal of the First-Year Experience \& Students in Transition, 15(1), 19-38.

Gianakos, I. (1999). Patterns of career choice and career decision-making self efficacy. Journal of Vocational Behavior, 54(2), 244-258.

Harlow, A. J., \& Bowman, S. L. (2016). Examining the career decision self-efficacy and career maturity of community college and first-generation students. Journal of Career Development, 43(6), 512-525.

Hassan, M. (2008). Adolescent Self Concept and Vocational Aspiration among secondary school students in Bornu State Nigeria. Journal of Education and Applied Psychology, 1(1), 2008.

Mahadi, H. N. A., Ph'ng, L. M., Hasan, H., \& Ariffin, H. (2016). Self-Esteem, Social Support, and Career Decision-Making Among Technical Engineering Students. Conference: 4th International Conference on Technology Management, Business and EnterpreneurshipAt: Kings green Hotel Melaka, Malaysia.

Jelas, Z. M., Salleh, A. M., Azman, N., Hamzah, R., Jani, R., Hamzah, H., \& Abd Hamid, Z. (2013). Laporan Penyelidikan: Analisis gender dalam pendidikan. Kementerian Pendidikan Malaysia.

Joo, H. S. (2014). The Relationship Among Work Adjustment, Pre-Entry Knowledge Post Employment Expectation, Proactively, Organizational Socialization Strategic, and Social Support at Work of University Graduate Newcomers in Large Cooperation. Doctoral Dissertation.

Kelly, K. R., \& Shin, Y. J. (2009). Relation of neuroticism and negative career thoughts and feelings to lack of information. Journal of Career Assessment, 17(2), 201-213.

Kline, R. B. (2005). Principles and Practice of Structural Equation Modeling (2nd ed.). New York: Guilford.

Kotrlik, J. W. K. J. W., \& Higgins, C. C. H. C. C. (2001). Organizational research: Determining appropriate sample size in survey research appropriate sample size in survey research. Information technology, learning, and performance journal, 19(1), 43-50. 
Luzzo, D. A. (1993). Value of career-decision-making self-efficacy in predicting career decisionmaking attitudes and skills. Journal of Counseling Psychology, 40(2), 194-199.

Li, Y. I., Hazler, R. J., \& Trusty, J. (2017). Relational self-construal as a moderator of social support in career decision making. The Career Development Quarterly, 65(1), 44-56.

Maslow, A. H. (1943). A theory of human motivation. Psychological Review, 50(4), 370-396.

Mojgan, F. N., Kadir, R. A., Noah, S. M., \& Hassan, S. A. (2013). The relation of career indecision and parental attachment among Iranian undergraduate students. International Journal for the Advancement of Counselling, 35(4), 251-260.

Montgomery, M. J., \& Côté, J. E. (2003). College as transition to adulthood. In Adams, G. R., \& Berzonsky, M. D (Eds.), Blackwell Handbook of adolescence (pp. 1-643). Oxford: Blackwell.

Maznizam, M., \& Abdullah, M. R. (2013). Career indecision : A cross-sectional survey among students of National Youth Skills Traning Institutes. Middle-East Journal of Scientific Research, 17(8), 1073-1107.

Penn, L. T., \& Lent, R. W. (2018). The joint roles of career decision self-efficacy and personality traits in the prediction of career decidedness and decisional difficulty. Journal of Career Assessment, 20(10), 1-14.

Park, I. J., Kim, M., Kwon, S., \& Lee, H. G. (2018). The relationships of self-esteem, future time perspective, positive effect, social support, and career decision: A longitudinal multilevel study. Frontiers in psychology, 9, 514.

Resnick, H., Fauble, M. L., \& Osipow, S. H. (1970). Vocational crystallization and self-esteem in college students. Journal of Counseling Psychology, 17(5), 465-467.

Rosenberg, M. (1965). Society and the adolescent self-image. Princeton, NJ: Princeton University Press.

Salkind, N. J. (2010). Encyclopedia of research design (Vols. 1-0). Thousand Oaks, CA: SAGE Publications, Inc.

Simons, J. A., Irwin, D. B., \& Drinnien, B. A. (1987). Maslow's hierarchy of needs. Retrieved October, 9(2009), 222.

Super, D. E., Brown, D., \& Brooks, L. (1990). Career choice and development: Applying contemporary theories to practice.(2nd ed.). Jossey-Bass.

Santrock, J. W. (2014). Adolescence (15th ed.). New York: McGraw-Hill Education.

Taylor, K. M., \& Betz, N. E. (1983). Applications of Self-Efficacy Theory to the Understanding and Treatment of Career Indecision, 81, 63-81.

Talib, M. A., \& Aun, T. K. (2009). Predictors of career indecision among Malaysian undergraduate students. European Journal of Social Sciences, 8(2), 215-224.

Turner, S. L., Alliman-Brissett, A., Lapan, R. T., Udipi, S., \& Ergun, D. (2003). The Career Related Parent Support Scale. Measurement \& Evaluation in Counseling \& Development, 36(2), 83-94.

Vondracek, F. W., \& Porfeli, E. J. (2003). The world of work and careers. In Adams, G. R., \& Berzonsky, M. D (Eds.), Blackwell Handbook of adolescence (pp. 1-643). Oxford: Blackwell.

Wang, N., Jome, L. M., Haase, R. F., \& Bruch, M. A. (2006). The role of personality and career decision-making self-efficacy in the career choice commitment of college students. Journal of Career Assessment, 14(3), 312-332.

Wang, C. M., Qu, H. Y., \& Xu, H. M. (2015). Relationship between social support and self-efficacy in women psychiatrists. Chinese Nursing Research, 2(4), 103-106.

Zhang, H., \& Huang, H. (2018). Decision-making self-efficacy mediates the peer support 
INTERNATIONAL JOURNAL OF ACADEMIC RESEARCH IN BUSINESS AND SOCIAL SCIENCES Vol. 11, No. 8, 2021, E-ISSN: 2222-6990 @ 2021 HRMARS

career exploration relationship. Social Behavior and Personality: an international journal, 46(3), 485-498. 